\title{
Development of Administration Quality In Madrasah Tsanawiyah'Aisyiyah, Medan
}

\author{
Deliati, Nur Sakinah, Nadlra Naimi \\ University of Muhammadiyah Sumatera Utara, Indonesia \\ deliati@umsu.ac.id
}

\begin{abstract}
Partners in this research are Madrasah Tsanawiyah Swasta 'Aisyiyah Pasar Merah and Madrasah Tsnawiyah Swasta Islamiyah Belawan. The existence of schools 'Aisyiyah is equipped with school administration as a means of supporting learning resources and student learning success. As one source of learning in schools, administration helps achieve school quality improvement. Considering the importance of school administration, it is necessary to have a neatly arranged management effectively and efficiently so that the high quality administration functions of the school in order to improve school accreditation can really be realized. The purpose of the administration of Madrasah Tsanawiyah is to advance a school if the administration is neatly arranged and systematic so that it can improve the quality of schools and principals and students. Management of Administration in Madrasah Tsanawiyah Swasta'Aisyiyah is still inadequate, as stated in Article 35 paragraph (2) Government Regulation Number 19 of 2005 concerning National Education Standards needs to stipulate Minister of National Education Regulation on School / Madrasah Administrative Standards. However, the problems found were not a few school administrations whose management was not professional. This is due to the understanding that the school administration still does not understand about managing the school administration properly. The target to be achieved through this PKPM activity is the development of school administration management for Madrasah Tsanawiyah Swasta 'Aisyiyah which is effective and efficient. Implementation methods carried out (1) Preparation of deliberations with partners, PWA Majelis Didasmen Wilayah and Madrasah Tsanawiyah Swasta'Aisyiyah (2) Implementation (actions) fostering management of school administration' Aisyiyah, (3) Observation of management of school administration 'Aisyiyah, (4) Evaluation The Administration Management Development Checklist, and (5) Reflections on Administratio of Madrasah Tsanawiyah Swasta 'Aisyiyah.
\end{abstract}

Keywords : management, administration; Madrasah Tsanawiyah Swasta 'Aisyiyah

\section{Introduction}

Administration is an activity that involves human resources. If associated with education, education administration is "an activity aimed at optimizing (effective and efficient) the achievement of educational goals through structuring various resources, people, curriculum, and facilities. One of the points in the verse can be seen in the following section:

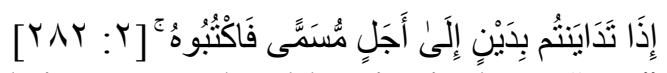
Meaning: if you are not in cash (owed) for a specified time, you should write it down." ..."

(Surah Al-Baqarah / 2: 28)

School administration activities are the spearhead of the overall education administration activities. Supandi (2008) argues that education administration is an administration applied in the field of education. All aspects of activities to utilize a variety of sources (human, facilities and infrastructure, as well as other educational media) in an optimal, relevant, effective, and efficient manner to support educational attainment. In the opinion of Daryanto (2008) argues that education administration is a series of activities or the whole process of controlling the efforts of collaborating a number of people to achieve educational goals in a planned and 
systematic manner held in certain environments, especially in the form of formal education institutions.

Madrasah Tsanawiyah is an educational institution that is equivalent to a junior high school that has Islamic characteristics that are managed and developed under the auspices of the Directorate of Primary and Secondary Education 'Aisyiyah PWA Medan City and the Ministry of Religion of the Republic of Indonesia. Whereas 'Aisyiyah is a place of struggle and charity for Muhammadiyah women. His position as the Special Autonomy Organization of Muhammadiyah is not the same as other Autonomous Organizations because 'Aisyiyah's movements and activities are balanced with the movements and activities of Muhammadiyah men. 'Aisyiyah was declared a Special Autonomy Organization as an educational institution that has Islamic characteristics. This can be seen from the small number of administrative personnel available at the school, where administrative staff have a dual role not only as administrative staff but also teaching as a teacher so that the main tasks as administrative staff do not run optimally.

Rukmana (2015) revealed that "School Administration Staff is one part of the education staff whose existence cannot be separated from the effectiveness of the school program. Based on Law Number 20 of 2003 article 39 paragraph 1, it has been explained that "Educational staff are tasked with carrying out administration, management, development, supervision and technical services to support the educational process in the education unit. Administrative Arrangement for Madrasas Tsanawiyah becomes so important as the main data source of madrasas in regulating the teaching and learning process in an orderly manner so that the achievement of the goals of madrasas. More specifically the administration of madrassas functions: (1) giving direction in the delivery of madrasah education, (2) providing feedback on improving educational processes and outcomes in the madrasah, (3) improving the quality of madrasah administration, (4) supporting the achievement of madrasah goals / programs effective and efficient. At present the madrasa arrangement refers to 8 national education standards. Which is often problematic in the field, namely regarding the types of administration that refers to 8 standards. The standard to be achieved is by the madrasa, namely: (1) standard administration of content, (2) standard administration of processes, (3) administration of standards of custody competency, (4) administration of PTK standards, (5) standard administration of facilities and infrastructure, (6) Standard Administration of Management, (7) Standard Financing Administration, (8) Assessment Administration. The role of madrasah administrative staff is very important in supporting the success and smooth administration of the school administration. In dealing with school administration procedures, it requires sufficient expertise and ability in the administrative field. Therefore, human resources in this case administrative staff become an important component in a school. Because the role of administrative staff in a school is likened to a life that depends on its physical form.

\section{Research Method}

Problem of the study based on the results of services carried out by the PKPM Implementation Team as described in the introduction, it can be concluded that the partner problem solving framework is as follows:

1. Prepare to guide MTs teachers to improve administrative discipline of Madrasah Tsnawiyah teacher. 
2. In optimal administration of Madrasah Tsnawiyah, the efforts of the madrasah leaders in realizing Madrasah Tsnawiyah with 8 SNP standards.

3. Administrative guidance is still in the process of the dedication team of the School of Administration 'Aisyiyah development carried out in practice by using a module instrument for achieving accreditation so that the quality of the madrasa is of high quality

4. Evaluating madrasah administrative development activities "Aisyiyah with several meeting materials that have been socialized by the implementing team of lecturers and experts from the junior high school LPMP.

5. Reflecting on Participants through madrasah administrative guidance given material about what the roles and objectives are, the need for school organizational structure contributes to the success of madrasah administration in order to get an A grade accreditation rating

Based on the partner problems described above, the PKPM method used is as follows:

1. Using a comprehensive training method to realize effective and efficient madrasah administration

2. Utilizing competent and professional HR tutors in the field of school administration and empowering teachers and principals as a team to implement quality school administration.

3. Providing solutions to problems faced by partners related to Madrasah administration

\section{Discussion}

The PKPM team explained about madrasah administration with the help of the resource person to explain about the Madrasah Tsanawiyah Administration that was effective and efficient and quality, not only the ability in the form of goods or infrastructure but the principal, teacher and staff as well as materials for becoming Tsanawiyah madrasas were accredited with high value if all 8 standards are implemented. Mrs. Sri kemala Khairani M.Pd. he is the supervisor of SMP/Mts said: "the role of madrasah administration is very important for the continuing implementation of education in schools. Administration is a joint effort to utilize resources both personally and material effectively and efficiently in order to support the achievement of the goal of school education optimally. "This service activity according to him that school administration is practical and flexible, can be implemented in accordance with the conditions and real situations in school, its function as a source of information for improving management of education and teaching and learning activities. School administration is closely related to school accreditation activities.

Why? Accreditation is an assessment activity carried out by the government to determine the feasibility of an education unit program using instruments and criteria that refer to the National Education Standards (SNP). The school administration that refers to the SNP 8 criteria is an illustration of the seriousness of schools and the government to work together in advancing the quality of education in the school. A good administration will support good accreditation assessments. Schools that have arranged their administration in accordance with 8 national education standards will be easy for assessors to provide appropriate and accurate assessments. Schools that have an 'A' accreditation rating are schools that have prepared all the completeness documents of each standard and implemented it well as well. 


\section{Conclusion}

The Muhammadiyah Development Partnership Program (PKPM) was achieved through coaching activities by Masyarakat Madrasah Tsnawiyah Aisyiyah. Scientific insight, evaluation checklist, and guidance through special training and several stages of activities, namely (1) Preparation of Activities with Partners of both partners (2) Implementation (actions) Administration of Madrasah Tsanawiyah (3) Observation Administration of Madrasah Tsanawiyah (4) Evaluation Fostering administration of Madrasah Tsanawiyah Library Management, and (5) Reflection on administration of Madrasah Tsanawiyah. At present the madrasa arrangement refers to 8 national education standards. Which is often problematic in the field, namely regarding the types of administration that refers to 8 standards. The standard to be achieved is by the madrasa, namely: (1) standard administration of content, (2) standard administration of processes, (3) administration of standards of custody competency, (4) administration of PTK standards, (5) standard administration of facilities and infrastructure, (6) Standard Administration of Management, (7) Standard Financing Administration, (8) Assessment Administration.

\section{References}

M. Daryanto. 2008. Administrasi Pendidikan. Jakarta : Renika Cipta.

Supandi, 2008. Administrasi Pendidikan dan Supervisi Pendidikan. Jakarta Universitas Terbuka.

Rukmana, I. J. 2015. Pengaruh Pengawasan Melekat oleh Kepala Tata Usaha terhadap Kinerja Staf Administrasi di SMP Negeri se-Kecamatan Majalengka. Bandung: Universitas Pendidikan Indonesia

Undang-Undang Nomor 20 Tahun 2003 tentang Sistem Pendidikan Nasional

(Sisdiknas) Pasal 39 ayat 1. Jakarta: Kementerian Pendidikan Nasional 